\title{
Forms Of (In)visibility In Recent Spanish Films On Basque Terrorism
}

\author{
Jaume Martí-Olivella
}

\section{Synopsis}

This essay explores the omnipresence of the subject of (Basque) terrorism in Spanish political discourse and media representations in ways that construct the average citizen as both victim and voyeur of a terrorist subject always already rendered invisible either by its reduction to a legal "bare life"or by its figuration in terms of the unspeakable. My analysis centers on Jaime Rosales' Bat Buruan/Tiro en la cabeza/Bullet In The Head,2008, arguably the most radical and unsettling of the Spanish cinematic figurations of the terrorist subject to date, where the spectator is forced to occupy such a paradoxical position as both victim and voyeur. In geopolitical terms, Rosales' film is also especially intriguing since it portrays ETA's first killings on French soil, which further complicates the issue of the (Spanish) State as the (invisible) enemy.

\section{Biography}

Jaume Martí-Olivella teaches in the Languages, Literatures and Cultures Department at the University of New Hampshire. He co-founded CINE-LIT in 1991. He is also cofounder and former president of the North American Catalan Society. He is the author of Basque Cinema: An Introduction (Center for Basque Studies, 2003) and co-editor of the volume Spain is (Still) Different: Tourism and Discourse in Spanish ldentity. (Lexington Books,2008). He has also co-edited five CINE-LIT Proceedings (1992, 1995, 1998, 2001,2003.

\section{Essay}

\section{Framing the Isue: The Current Context}

1. Are we all invited? The place of the citizen as spectator in Spain today.

Todos estamos invitados (Everyone Is Invited, 2008)is the significant title chosen by Manuel Gutiérrez Aragón for his 2008 film portraying an amnesiac ETA patient, his female caretaker and a university professor threatened by ETA for his critical statements regarding the political situation in the Basque Country. The significance of Gutiérrez Aragón's title is double edged. It suggests that all of us may become targets of terrorism, that is, that we all share in the potential of becoming victims while ironically stating that, in fact, not all of us are truly invited to be part of a (Basque) community that is portrayed as being constituted both by fear and by exclusion. And yet, there seems to be little room for choice in the subject position we take in Spain's current battle over victimhood and political legitimacy. Are we all (still) Miguel Angel Blanco?, the leading 
question posed by Justin Crumbaugh in his groundbreaking essay, (Crumbaugh 2007)both echoes and undermines the one implied in Everyone Is Invited since it reiterates the continued potential to become a victim while, at the same time, exposing the symbolic fixation upon victimhood as the only political discourse available. In short, we, the Spanish citizens, are not invited but forced to become spectators of the symbolic battle inside Spain's body politic. In Crumbaugh's own words:

A striking development in Spain since the late 1990s is the extent to which the victims of political violence have increasingly become more of a media spectacle than the terrorist themselves. ... Since Blanco's assassination, victims of ETA constitute a kind of ideal ego of a new, seemingly incontrovertible model of democratic statesmanship. (Crumbaugh 378).

That is why, I believe, Jaime Rosales' Bat Buruan/Tiro en la cabeza (Bullet in the Head, 2008), the film that will be my textual focus in this presentation, becomes such a powerful and unsettling representation of the current situation. Indeed, Rosales ' film forces the spectator to occupy a rather paradoxical voyeuristic position where there is practically no choice for either identification or scopic gratification. As viewers, from the beginning, we are stuck as outsiders looking in without ever being privy to a word or a thought of the terrorist subject whose daily routine, together with Rosales' camera, we ceaselessly scrutinize throughout most of the film.

\section{2.. ETA's Recent Cinematic Representations as Forms of (In)visibility}

Rosales' paradoxical portrayal of the terrorist subject relies nevertheless on the most common topos associated with it: its invisibility. I would be hard pressed to find any Spaniard of my generation who has failed to see images of ETA press-conferences with its masked members surrounding the ax and snake emblem of the group. Rosales' film takes off that piece of clothing to show us that the true mask, that is, the true invisibility of the terrorist subject is precisely the mask of his/her normalcy. There are, nevertheless, other forms of visible invisibility in Rosales' film. More important among them is the absent presence of the history of ETA's cinematic representations which have, more often than not, been ignored by most of the film reviewers and which inscribe Rosales' own belief in historical memory as the only space where the Basque conflict may overcome its present and unintelligible "evil" reduction/ism. None of the other films dealing directly or indirectly with this topic produced outside Euskadi in the last decade completely escapes this reductionism. All those I know, despite their ideological and aesthetic differences, may be seen as portraying different forms of (in)visibility of a terrorist subject that is always constructed as either voiceless, spectral, or literally invisible. Such invisibility will be highly paradoxical in Jaime Rosales' Bullet In The Head, the film that will center my discussion. Rosales' kidnapped viewer and his/her fixed contemplation of the daily routine of the terrorist subject does not ultimately render him more visible, that is, more understandable but keeps him always at both a literal and a symbolic narrative distance that ultimately forces us to interrogate our own positionality as viewers and as potential victims (or accomplices) of terrorism. 
Carlos. Martín Ferrera's Zulo (Hole, 2005) is certainly the most abstract formulation of the subject by taking us literally with Miguel, his protagonist, inside the "zulo" of the title, that deep dug hole shaped as a circular well where he is kept by two masked men who will never tell him why he is there or what will happen to him. The film offers no clue as to its connection with Basque terrorism. The only one is the known reality that ETA has used many similar spaces to hide both kidnapped men and weaponry. The other hint is the protagonist's name: Miguel, a name that almost echoes that of Miguel Angel Blanco, the well-known ETA victim mentioned before. Shot almost entirely within the narrow space of the well, Martín Ferrera's film focuses on the self-destructing process of the trapped man until showing his final "liberation" while the voiceover narration tells us and him that it is already too late, and, in so doing, it becomes an extreme metaphor for modern man's mad situation and profound alienation.

Miguel Courtois' GAL. En el punto de mira (GAL. On Target, 2006) is a very strong indictment of the Spanish government's direct sponsorship of the GAL (Grupos Antiterroristas de Libreación) in the 1980s, when Felipe González was Spain's prime minister as leader of the PSOE (Spanish Socialist Party). And yet, most of its political clout is lost by its own partisanship. In between the genres of docudrama and political thriller, Courtois' film becomes prisoner to its own lack of restraint, mainly, by falling into an almost gratuitous spectacularization of violence and also by turning mister Ariza, the tough contact man in real life into an almost ridiculous womanizer and drug abuser in the film. The fact that Melchor Miralles, the real-life journalist who uncovered the GAL scandal and El Mundo, the conservative newspaper where he still works today, are an essential part of the producing team of the film does indeed add credibility to its contents although it also contributes to the above mentioned partisan view. Despite its artistic flaws, this film is an important document since it sheds light on an obscured case of State sponsored terrorism in Spain. From the perspective of this essay, however, it becomes another instance of invisibility inasmuch as the ETA terrorists are here portrayed mainly as the anonymous victims of the GAL activities.

Manuel Gutiérrez Aragón's Todos estamos invitados (Everyone Is Invited, 2008), as stated at the beginning of this essay, becomes a clear illustration of the general predicament that we are all invited, that is, that we are all potential targets of terrorist violence. In its portrayal of the specificities of the Basque political conflict, however, the film restricts the scope of its central metaphor to mean that we are not all truly invited to attend the functions of the "sociedades gastronómicas," the exclusive and exclusively male Basque dining clubs that Gutiérrez Aragón singles out as symbols of the entire Basque society. It is in one of those that Xabier, the lead character played by José Coronado, finds that his presence is no longer as welcome as it had been before his constant critical statements regarding the use of violence in Euskadi puts him outside 
this communal agape. The fear, and in some cases, the resentment of some of his peers will lead to further violence and exclusion. Shot also under the conventions of a political thriller, the film never quite manages to provide enough political background to sustain its historical claims. And, once again, when it comes to the direct representation of the terrorist subject, embodied here by the character of Josu Jon played by Oscar Jaenada, the director chooses to render him amnesiac as a result of head injuries when he was escaping a police chase. Amnesia, thus, becomes the film's second large metaphor. As such, it allows the director to inscribe not only the issue of historical memory but also the question of who will be able to claim the right narrative once the fight is over.

\section{Jaime Rosales' Bat Buruan/Bullet in the Head in Cinematic and $\underline{\text { Theoretical Context }}$}

1. In Between Hitchcock's Rear Window and Ford Coppola's The Conversation.

A lot has been written about the controversy surrounding Rosales' last film. Very little has been said, however, regarding the film's cinematic intertextuality and its theoretical implications. Although Rosales' filmmaking is more generally credited to be influenced by Robert Bresson's understatement and by Yasujiro Ozu's stillness, the two essential intertexts here come from Hollywood, as Núria Vidal's review already suggests:

The first sequences of Tiro en la cabeza send us directly to the beginning of Francis Ford Copola's The Conversation (1974). We see, but we can't hear. We know who the camera follows but we don't know why. We have an intuition of what is said by means of the facial expressions, but we can't find out who is behind the characters to behave like they do. When the action shifts to the interior of the houses, the referent changes. Here we are inside the domain of Hitchcock's 1954 Rear Window. People behave in their houses with a naturalness that makes you think nobody is watching. Unlike James Stewart's neighbors, whom we see as if acting in small theaters, Rosales positions himself with his framing technique and proposes each shot as a frame within a frame, (or a picture within a picture), both fragmented and determined by a doorframe, a window frame or the railing of a balcony. If, at the beginning, we felt like spies, now we have become voyeurs of an absolutely banal intimacy that we witness in real time, which in the film translates into a lengthening of cinematic time. (Vidal 44. My translation).

There is, I should add, an important difference between Rosales' film and these two major Hollywood references and that has to do with the spectator's positionality. Thus, if we as viewers soon fall for Stewart's voyeurism and end up as his accomplices in Rear Window or, if we feel truly intrigued and thus willingly become spies in The Conversation, it is almost impossible to say the same about Rosales' film. \Here, if anything, we feel literally trapped, almost kidnapped, into being both spies and voyeurs. 
Both subject positions are however subverted in Rosales' film since the voyeur is not the protagonist but the spectator while the protagonist is the object of the scopic intrusion, while, as spies, our prying into the character's private life always fails because we are never allowed to hear his conversations. Neither true policeman nor true voyeur, the viewer is forced to remain at the same time intimately close and quite remote from its intruded subject, just as we, ordinary people, are forced into constant contemplation and practical silence amidst the "conversation" between the terrorist subject and the State, its invisible enemy. Technically, moreover, the radical distance imposed by Rosales' telephoto lens acst as a Brechtian device that shortcircuits any possible identification. At best, we remain intimate strangers. A proposition that seems to betray Rosales' own view not only of our fragmented society but of the human condition at large.

There is, on the other hand, a significant political coincidence between Rosales' and Ford Coppola's proposition. Thus, if Coppola's film, despite the director's disclaimers, was read as a direct critique of the illegal surveillance devices used by the Nixon administration to spy on their political foes, Rosales' film was released in the context of a number of political scandals surrounding corruption and also illegal tappings in Spain. Concerning the film's voyeurism, it may be necessary to go back briefly to Freud's own definition of the term which he always related to that of scopophilia:

But my researches into the early years of normal people, as well as of neurotic patients, force me to the conclusion that scopophilia can also appear in children as a spontaneous manifestation..... Children of this kind turn into voyeurs, eager spectators of the processes of micturition and defaecation. (Freud in Gray 269. My emphasis.).

There are, at least, three aspects in the portrayal of voyeurism in Rosales' film that I find worth mentioning in relationship with Freud's definition. First, as I have already suggested and due to Rosales' closed scopic regime, we, as viewers, are not "eager" but forced spectators of the terrorist's private life. Secondly, again due to Rosales' constant juxtaposition of passing obstacles or viewing partial barriers, such as the windows and doors themselves but also such as the garbage containers that often block the view of the protagonist, we can only obtain partial and fragmented visions of the (undesired) subject of our contemplation. More importantly, Rosales seems to imply a direct albeit dramatically ironic reference to Freud's definition with those frequent images of garbage containers as blocking devices because, unlike the eager children exploring other people's genitalia and their basic functions, what Rosales inscribes here is the inevitable encounter with our own garbage, both in quite literal and also in metaphorical terms. In doing so, the director not only echoes one of the central metaphors in the representation of ETA terrorism within Basque (and Spanish) cinema, but also hints at the persistence, if not at the hegemony, of the "excremental" over the "sacramental" in our daily lives. ii 


\section{Spectral Traces of Basque Cinema's Historical Representation of ETA.}

As mentioned earlier, the recurrent presence of the garbage metaphor directly connects Rosales' film with many previous cinematic renderings of ETA on screen, both in Euskadi and in the rest of Spain. More interesting than that almost conventional marker, there are quite a number of subtle references to crucial Basque films on the subject that are almost always tangentially,even spectrally, inscribed in Rosales' narrative. To my knowledge, none of these references has been critically discussed, a fact, I believe, that is due in large part to the almost non-existence of studies that deal with Basque cinema as an autonomous entity

One of the most interesting of those visual traces alluding to previous Basque cinema is the emphasis on the back, and, more especifically, on the nape of the protagonist. The first occurrence of this in Rosales' film happens in conjunction with the already mentioned garbage metaphor. I am referring to the first sequence in daytime where we see the backpack and the nape of the protagonist as he moves about the press kiosk and is partially blocked by what looks like a small garbage container placed between the camera and the character. From then on, we will see Jon Arretxe's back and nape repeatedly while he is calling, getting money from an ATM teller machine, or listening to a record within a music shop. More significantly, we will also see only his bare back and nape in the sequence where he is kissing and embracing his girlfriend. It is here where Rosales alludes to Helena Taberna's film Yoyes (2000), which repeatedly used the visual emphasis on the protagonist's nape to inscribe a sense of vulnerability and foreboding. iii

The intertextual connection between Rosales' and Taberna's films has, moreover, another important element which acts both as framing device and as narrative metaphor: the constant use of windows framing the characters and our vision of them. In her film on María Dolores González Katarain, alias Yoyes, Helena Taberna paid special attention to her lead character both central and liminal position within the commanding structure of ETA. Yoyes' final rejection of the group's violent methods ultimately was paid with the sacrifice of her own life. Besides stressing Yoyes' victimhood status, Taberna's film uses her posthumously published diary, Desde mi ventana (From My Window, 1988) as a constant frame of reference which the director visually inscribes in a series of shots through and from several of the windows appearing in the fillm. ${ }^{\text {iv }}$ Needless to say, both Taberna and Rosales seem to rely on the rich ambiguity of the very notion of framing and being framed, that is, fragmenting and being trapped, which both their real and symbolic window framing strongly illustrate. 
Besides the references to Ana Díez's Ander eta Yul and to that of HelenaTaberna's Yoyes, Rosales' film also includes traces of the work of Imanol Uribe and Julio Medem, whose El proceso de Burgos (The Burgos Trial, 1979) and La pelota vasca. La piel contra la piedra (Basque Ball. Skin Against Stone, 2003) constitute the two most important documentary films on the Basque political scene to date. Both films are clearly although tangentially invoked in Rosales' Bullet in the Head. Thus, the Burgos plates of the car that the terrorists use in their trip to France inevitably brings to mind that city as both the location of Franco's first government and of the collective trial of the ETA members that also took place there during the seventies. The initial sound and vision of the sea followed by noises of a Basque ball court in the background used by Rosales in the beginning of his film also force us to think of a similar, although much more clearly pronounced, initial sequences in Julio Medem's epochal documentary. Rosales himself has often quoted Medem's work in interviews. What seems partly uncanny here is the fact that Rosales cast Jon Arretxe for his lead role, apparently without knowing about Arretxe's past, specially his having been arrested and tortured by the Guardia Civil under unproven charges of belonging to ETA when he was only twenty-one years old. Doubtelessly, Rosales must have been conscious of Imanol Uribe's own gesture of casting five real life ex-prisoners of ETA, including Patxi Bisquert, future icon of the Basque cinematic screen, and Angel Amigo, co-screenwriter and producer of La fuga de Segovia (Escape From Segovia, 1981), the film that chronicled the historical and partly tragic escape from the Segovia prison. What the inclusion of these historical and cinematic traces adds to Jaime Rosales' film directly points to his own conviction that it will be only by acknowledging the importance of historical memory that we will be able to find a middle or common ground where the necessary dialogue may take place in and about the Basque Country if Euskadi is to reach any political normalcy.

\section{Rosales' Bullet in the Head and Agamben's "Threshold of indistinction."}

Agamben's crucial notions of "bare life," "homo sacer," and "state of exception" have been all called for in substantive ways in recent essays on Basque terrorism. ${ }^{\vee}$ That is why I will limit myself here to suggest a possible linkage between Giorgio Agamben's theoretical work and Jaime Rosales' Bat Buruan/Tiro en la cabeza. For that, I want to recall here the Italian thinker's notion of a "threshold of indistinction:"

What had to remain in the collective unconscious as a monstrous hybrid of human and animal, divided between the forest and the city - the werewolf - is, therefore, in its origin the figure of the man who has been banned from the city. ...The life of the bandit, like that of the sacred man, is not a piece of animal nature without any relation to law and the city. It is, rather, a threshold of indistinction and a passage between animal and man, physis and nomos, exclusion and inclusion: the life of the bandit is the life 
of the loup garrou, the werewolf, who is precisely neither man nor beast, and who dwells paradoxically within both while belonging to neither.

(Agamben105. First emphasis mine.).

If we substitute the word bandit with the word terrorist in Agamben's previous proposition, we can see how Rosales' film may be perceived as a visual reenactment of the werewolf predicament today. Specifically, the film takes us from the semi-darkness of the terrorist city dwelling into the emptiness of the forest trail where we see him for the last time. Rosales thus marks the two symbolic points placed at the extreme of Agamben's "threshold of indistinction" and makes us aware, once again in Agamben's own worsds::" [that] it is not so much a war of all against all as, more precisely, a condition in which everyone is bare life and a homo sacer for everyone else." (Agamben 106). Like Agamben's reasoning, Rosales' film is also based on the figure of the paradox. Indeed, with his relentless scrutiny of the Basque terrorist daily routine before showing his wolf-like metamorphosis, Rosales manages to depict both and at the same time the subject's "bare life" as simple and banal and as homo sacer, that is, the life of the liminal, monstrous figure at the midst of our democratic societies.

\section{Jaime Rosales' Bullet in the Head: From "The Terrorist Subject" to "The Subject of Terrorism."}

\section{Rosales' Portable Panoptikon and the "Bare Life" of the Terrorist Subject}

It should be quite obvious, by now, that Jaime Rosales' Bullet in the Head is aimed at provoking the regular expectations of most filmgoers. The director himself has plainly stated it: "I am a quiet and moderate man but my cinema is not. It portrays violence. I do violence against conventional cinema." (Rosales in Vidiella, 18. My translation.). Fisrt and foremost in Rosales' violence of representation is, of course, his choice to leave the terrorist subject speechless or, at least, inaudible. And, paradoxically enough, this radical gesture obeys the director's ethical claim that we need to listen to the other if any solution is to be found. This silent representation of the terrorist's bare life, he suggests, forces the viewer to reconsider his/her own position in the face of political violence. Needless to say, such decision is viewed by some as truly senseless since it replicates the very silence that the terrorists want to impose. A silence that Fernando Savater claims was always present during the San Sebastián Film Festival which, according to him, had never uttered any public message of rejection against the violence of ETA until 2008, the very year of Rosales' film opening there. ${ }^{\text {vi }}$

Fernando Savater is one of the most prominent examples of what Joseba Gabilondo calls "organic intellectuals." If I have emphasized the expression "the public eye" in Savater's words is because I believe it is at the heart of the issue here. Be it under the 
guise of the State's surveillance systems or the not so private eyes of the paperazzi' s cameras, what area of our private lives is not subject "to the public eye" in our world? One could almost say that the Foucaldian panoptikon has metamorphosed itself onto a portable telephoto lens that all of us are invited (forced) to use. In other words, we have become everybody else's "public eye."That might explain, to return to the specificity of Rosales' film, the second violent gesture of his proposal, namely, to subject us, the viewers, to look through such a reductive device. A device, that as Alex Gorina reminds us: "eliminates the depth of field and all the contours and creates a succession of frames where human figures coexist at the same distance and with identical dimensions." (Gorina. 92. My translation). This is true although not quite. The framing distance is certainly not always the same during the long and silent portrayal of the protagonist's bare life. From the initial nocturnal window framing and the first shot of his nape in the press kiosk sequence, we will pass through images of Jon Arretxe, the actor who plays the lead role besides being the film's art director, at different distances, for instance, in the open space of a children's playground where we see him in profile speaking to a woman and child, who, in fact, are his real-life sister and nephew. Then, we will see him inside a coffee shop speaking with a friend, both of them in profile and framed by the window. Next, we will find him again in an open, and for the first time, clearly recognizable space, in the Amara railroad station in Donosti, where we see the EuskoTren arriving. The party he attends at night will again be portrayed as framed by windows and from the same initial distance. Besides showing us the banal aspect of the protagonist's bare life, what many of these silent shots share is a similar image of Arretxe's back and nape, which, as mentioned when discussing a similar emphasis in Helena Taberna's film Yoyes, suggests that Rosales is using a peculiar form of dramatic irony in stressing the vulnerability of his object of scrutiny, specially when most viewers know that he will be the one shooting on somebody else's head. Even during the seduction sequence, we will see only the protagonist's naked back in the foreground of the frame once again reframed by the window at night. Ultimately, Rosales seems to be saying, despite the viewer's forced voyeurism, the object of our private/public eye does not end up completely reified. In fact, the opposite seems to happen since it is his human vulnerability that gets stressed. This also explains why after that seduction scene, we will see again the protagonist in an almost uninterrupted series of shots from the back, first near an ATM teller, next making a phone call from a public telephone box, and then inside a music shop where he is listening to a record with the ear phones on, while the camera, in one of the few crude licenses of the film, focuses on the significant name of a pop band: the Sex Pistols. This long scrutiny of the terrorist's bare life will reach closure with the first textual mirror of the film, the repetition of the initial nocturnal shot where we now see the protagonist having supper framed and profiled by the lit window shining in the dark. The sequence ends though on a different register when Rosales panning stops on a bottle of oil outlined against the window frame in what constitutes a quasi "still life" that encapsulates the director' own aesthetic vision while suggesting what Hannah Arendt called "the banality of evil." vii Thus, at the heart of Rosales' film we encounter the figure of the paradox. Elsewhere, I have studied at length the central place that the figure of paradox has in Basque culture in general and in Basque cinema in particular. ${ }^{\text {viii }}$ Here, I would like to consider brieflyhow Rosales 
incorporates it as both a structuring principle and a social commentary. As a structural technique, it is used by employing a documentary, quasi non-narrative cinematic register to portray the fiction of the terrorist subject as "everyman." Then, when the film moves on and starts the recreation of a historical fact: the murder by ETA of two young Spanish civil guards in Capbreton in December 2007, Rosales shifts onto a fictional, almost traditional narrative format in order to carry out such a reconstruction. Taken almost at face value, when thinking of the title of this essay, Rosales' paradoxical performance renders the silent/silenced terrorist subject almost invisible or incomprehensible due precisely to his very excessive "visibility."

\section{The Return of the Gaze: The Cyclops' Eye.}

Most critics agree that the best sequence in the whole of Rosales' film occurs inside the coffee shop where the encounter between the terrorists and the Spanish civil guards takes place. ${ }^{\text {ix }}$ Before reaching that point, I want to briefly retrace our steps to focus on the moment of the second textual mirror of the film. This happens when we see the protagonist speaking with the same bearded friend we first saw during the sequence in the Amara railroad station. Now, we will see them getting into a red car which, driven by a young woman, will be soon reaching the French border, as the close-up shot of the "Frantzia $1 \mathrm{Km}$." road sign illustrates. Then, Rosales' camera will spend a few seconds portraying a pile of scrap by the road and the crane that is removing it, in another clear reminder of the garbage metaphor that, as I mentioned earlier, crisscrosses the entire film. As if needing a visual correlative to underline that he is taking us for the ride, Rosales includes a series of on the road shots that take us from the expressway into a local road flanked by tall plane and leafless trees until we reach a small chalet in the French village where the terrorists will spend the night.Then, for a moment, Rosales returns to the distant framing gaze to portray the terrorists again thorough a lit window as they now sit and smile while having dinner in what looks like a very pleasant evening. The sequence will end with a beautiful shot of a bowl of fruit sitting at the angle of the window, that inscribes the second almost painterly "still life" in Rosales' film. This distant stillness will be immediately changed by the background noise and the establishing shots of the sequence in the coffee-shop. Soon, the camera will pan onto the table where the three terrorists are having breakfast and, in passing through their figures in profile, we will distinguish a small ring on the girl's nose together with her Palestinianlike scarf, a fact that clearly marks her in generational terms, as if anticipating the final sequence where she will be marked in more specific gender terms when Rosales shows her almost compassionate look at the young French woman they have just tied to the tree in the forest.

Back in the coffee shop, we now see the young faces of the two civil guards whom, despite not wearing their regular uniforms, are easily recognizable by their strong Spanish features. They are now seen while paying the cashier in a camera movement that seems to stress the randomness of their presence together with that of the three terrorists in the same space of this self-service French coffee shop by the road. 
Interestingly enough, unlike what happened with the protagonist himself, the two civil guards appear facing the camera the first time we see them. At this moment of heightened tension, Rosales will resort to an almost traditional shot-countershot format to construct what has been commonly called, following the director's own allusion, the cyclop's eye scene. Indeed, a few seconds after one of the civil guards is left alone while his companion goes to the rest room, we see his eyes moving away from the menu and, in a quick almost freeze frame, finding and recognizing the table with the three terrorists. Almost immediately, just after the next counter-shot registers the sudden restlessness of the civil guard, the camera will show us the back of one of the terrorists that blocks part of the protagonists' face and thus lets us only see one of his eyes. And then, it happens, in another almost magnetic quasi freeze frame, we see the moment of final recognition and, thus, the beginning of the metamorphosis when that single eye becomes the cyclop's eye that fiercely returns our gaze and that of the young civil guard. What follows is a concise and, at the same time, brutal rendering of a cold blood killing, the conclusion of a foretold death where we are horrified witnesses of that bullet in the head anticipated in the film's title. Before the brutal shots, moreover, we are given the opportunity to hear the only clearly audible words in the film: "Txakurra, txakurra!" ( Dogs, dogs!), ${ }^{x}$ as if Rosales needed to add a verbal layer to stress that passage between human and animal, that "threshold of indistinction" described by Giorgio Agamben.

\section{Epilogue: Rosales' Double Criticism And Open-Ended Final Question.}

Rosales' collective implication will be reinforced by the film's finale. In this protracted last sequence, we accompany the terrorists and their kidnapped victim until they leave the main road to get into a rural path where, after momentarily leaving the car, they start walking through the forest with their victim, whom they finally leave blindfolded and tied to a tree.The slow tracking shot of the back of the shaking young woman tied and abandoned in the middle of the forest clearly intimates this idea of a collective victimization. This time, however, Rosales has showed us the face of the young terrorist girl trying to comfort and reassure the other woman whose crying we cannot hear. Again, as in passing, Rosales offers us a gender specific moment of hope, a further touch of humanity in the realm of the werewolf. The open endedness of the film is visually underlined by the long shot where we see the empty rural path after the car with the two terrorists have left the screen. This sequence recalls the ending of The Hours of a day, Rosales' first feature film, where the quiet taxi driver also abandons his would-be victim in the midst of a rural way. The sequence also seems to quote Luis Buñuel's The Discreet Charm of the Bourgeoisie (1972) and those absurd and memorable random walks on empty roads. Here, however, the "randomness" is presented in paradoxical terms which, as I mentioned earlier, may be interpreted as a visual embodiment of the homo sacer predicament described by Girogio Agamben, always already marking the limits of the city and the citizen. In the context of this essay, the viewers' final identification with the anonymous young woman tied to the tree seems to suggest an identical message to the one plainly stated in the title of Gutiérrez Aragón's film: We Are All Invited. Indeed, we are all invited as potential victims of terrorism and/or of random 
violence. And yet, Rosales' film does not end on this almost disarming and common sense notion. Just as his voyeuristic camera is contradicted by his anti-spectacular presentation of the terrorist subject, his final sequence stresses the film's double critique or, at least, its testimony to a double silencing, that of the terrorist and that of the victim, both voices subsumed (or erased) by the very violence of terrorism and by the State's appropriation of the discourse on terrorist violence. Ultimately, Rosales leaves us with a silent, and yet resounding, open-ended question: Who can (freely) talk about the subject of terrorism?

\section{Works Cited:}

Agamben, Giorgio: Homo Sacer. Sovereign Power and Bare Life. Trans, by Daniel Heller-Roazen. (Stanford: Stanford University Press, 1998)

Camí-Vela, María: "Entrevista con Helena Taberna." In Mujeres detrás de la cámara. Entrevistas con cineastas españolas de la década de los 90. (Madrid: SGAE/Ocho y Medio, 2001): 165-175.

Crumbaugh, Justin: "Are We All (Still) Miguel Ángel Blanco? Victimhood, The Media Afterlife, And The Challenge For Historical Memory?' Hispanic Review. Autumn 2007: 365-384.

Freud, Sigmund: "Three Essays on the Theory of Sexuality." In Peter Gray, ed: The Freud Reader. (New York and London: W. W. Norton and Co, 1989): 269.

Gabilondo, Joseba: "Terrorism, State Terror, and the Historical State of Exception. For a Postnational History of Violence in Spain and the Basque Country." Paper read at the "Revisioning Terrorism" Conference. (Purdue University, September 8-10, 2011)

Gonzáez Katarain, María Dolores: Desde mi ventana. (Pamplona: Pamiela, 1988) Gorina, Alex: "La mirada del cíclop." El Temps. September 30, 2008: 92.

Martí-Olivella, Jaume: "Invisible Otherness: From Migrant Subjects to the Subject of Immigration in Basque Cinema ." In William A. Douglass, Carmelo Urza, Linda White and Joseba Zulaika, eds: Basque Cultural Studies

(Reno: University of Nevada Press, 1999): 205-226.

Martí-Olivella, Jaume: Basque Cinema: An Introduction (Reno: Center for Basque Studies, University of Nevada, 2003)

Martí-Olivella, Jaume: Basque Cinema: The Shining Paradox. (Manuscript under consideration by Center for Basque Studies, University of Nevada, Reno)

Merino, Imma: "L'ull del cíclop." El Punt (Barcelona). October 13, 2008: 33. Mucha, Martín: "Jaime Rosales: 'Ya he hecho la película del nuevo atentado." El Mundo (Crónica). September 28,2008: 9.

Rodríguez Marchante. E: "La transformación del hombre-lobo en pleno día y en un café de Capbreton." $A B C$. October 3, 2008: 99.

Sánchez, Sergi: "Tiro en la cabeza. Un drama sin palabras." La Razón. October 3, 2008: 65.

Savater, Fernando: "íAllá películas! El País. September 30, 2008: 33. 
Vidal, Núria: "L'estrena de la setmana: Tiro en la cabeza." Time Out Barcelona October 3, 2008: 44.

Vidiella, Rafa: "Jaime Rosales: "Yo soy tranquilo y moderado, pero mi cine no." 20 Minutos Barcelona. September 24, 2008: 18.

Zulaika, Joseba: Basque Violence. Metaphor and Sacrament. (Reno: University of Nevada Press, 1988).

This film is almost a sequel to Courtois' El Lobo (The Wolf, 2004), where he portrayed also very forcefully, although with a much higher level of dramatic restraint, the real life infiltration of ETA by Mikel Lejarza, a Spanish State agent who managed to thwart almost a quarter of the group's terrorist activities between 1973 and 1975 before he was forced to assume a false identity and disappear for good.

ii See my essay "Invisible Otherness: From Migrant Subjects to the Subject of Immigration in Basque Cinema" where I first discuss the presence in Ana Díez' s film Ander eta Yul (Andrew and Yul,1988) of garbage as an extended metaphor for terrorism and, also, her conflation of the excremental and sacramental narratives as they are symbolized in the confrontation between the lead characters amidst the ruins of the old seminary of their youth. For a thorough analysis of the dramatic convergence of the excremental/sacramental dialectics in Basque culture, see Joseba Zulaika's Basque Violence. Metaphor and Sacrament..

iii Helena Taberna herself pointed out the significance of these shots in her interview with María Camí-Vela. See Camí-Vela's "Entrevista con Helena Taberna" in her volume Mujeres detrás de la cámara. Entrevistas con cineastas españolas de la década de los 90

iv I have studied these shots in some detail in "(En)Gendering ETA and/ in Basque Politics," an essay included as chapter four in my volume Basque Cinema: The Shining Pardox

vee, for instance, Justin Crumbaugh's previously mentioned essay or Joseba Gabilondo's own presentation to the "Revisioning Terrorism" Conference, entitled: "Terrorism, State Terror, and the Historical State of Exception. For a Postnational History of Violence in Spain and the Basque Country."

vi These are Savater's words: "The stifling sensation of cowardice, before one was afraid to talk but today, in a different climate and with the public eye set on what happens there, the dangerous thing is to remain silent. Savater, 37. My emphasis and translation)

vii Sergi Sánchez, in his review of the film for the Madrid daily La Razón, writes: "It is not a question of humanizing the terrorist and much less of justifying him. It is rather the fact of understanding our position as "voyeurs" and, more than anything else, of learning what it means the banality of evil that Hannah Arendt referred to." (Sánchez, 65). Giorgio Agamben also refers to Arendt's work several times throughout his Homo Sacer. Sovereign Power and Bare Life, and, especially in his chapter on "Biopolitics and the Rights of Man." (Agamben 126-135.

viii I am referring to Basque Cinema: An Introduction and to my manuscript Basque Cinema: The Shining Paradox, where I elaborate on the "ez//bai" polarity at the heart of Basque culture and on the fact of the visible invisibility of a cinematic corpus that, more 
often than not, goes unnoticed as an autonomous cultural entity and is absorbed in the Spanish logic of the self-same.

ix See, for instance, the already mentioned review by Alex Gorina, entitled precisely, "La mirada del cíclop," or the special emphasis and analysis given to that sequence in E. Rodríguez Marchante's review of the film for the ABC Madrid daily and also in Imma Merino's review also entitled "L'ull del cíclop" that was published in El Punt

x The word "txakurra" does indeed mean dog in Euskara although in political jargon it implies the meaning of "Spanish policeman." 